\title{
Does teacher-centered teaching contribute to students' performance in primary school? A video analysis in Mainland China
}

\author{
Zhao, Ningning \\ Beijing Normal University, China \\ Gent University, Belgium (tintinning@gmail.com) \\ Valcke, Martin \\ Gent University, Belgium (Martin.valcke@ugent.be)
}

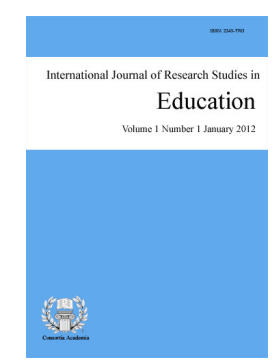

ISSN: 2243-7703 Online ISSN: 2243-7711

Desoete, Annemie

Gent University, Belgium (Annemie.desoete@ugent.be)

Sang, Guoyuan

Beijing Normal University, China (guoyuan.sang@gmail.com)

Zhu, Chang

Vrije Universiteit Brussel, Belgium (chang.zhu2010@gmail.com)

Received: 17 February 2014

Revised: 1 March 2014 DOI: $10.5861 /$ ijrse.2014.729

OPEN ACCESS

\section{Abstract}

The present study explores the nature and quality of the social interaction and the questioning approach during mathematics lessons in Chinese primary schools. A sample of 601 students and 9 teachers participated in the study. A multilevel analysis of mathematics performance reveals that: (1) the interactions raised by teacher contribute to the mathematics performance, and the interactions between student-student in public and interactions between teacher and one student have significantly positive impact on students' mathematics performance; (2) for the teacher questioning approaches, the evaluation and problem-solving play important roles on mathematics performance. The results suggest that the teacher-dominant interaction or student-dominant interaction have their own conditions under which they might have a positive impact. Questioning of the teachers should be focused on the cognitive thinking on the mathematics problems.

Keywords: interaction; questioning; teacher-centered; student- centered 


\section{Does teacher-centered teaching contribute to students' performance in primary school? A video analysis in Mainland China}

\section{Introduction}

Effective teaching and learning are expected to foster the construction of mathematical knowledge and skills and foster mathematical literacy (Wayne \& Youngs, 2003). A growing interest in evidence-based research focused on the detection of key instructional approaches (see e.g., De Corte, 2004; Seidel \& Shavelson, 2007). For instance, the 1995 and 1999 Third International Mathematics and Science Study (TIMSS) explored teaching patterns and effective teaching approaches in mathematics instruction on the base of video observation (Hiebert, Gallimore, Garnier, Givven, Hollingsworth et al., 2003; Stigler, Gonzales, Kawanaka, Knoll, \& Serrano, 1999). This type of studies helped to develop a basic understanding of particular instructional processes and helped to develop a knowledge base about similar pedagogical cultures in a particular country (Hugener, Pauli, Reusser, Lipowsky, Rakoczy, 2009; Kunter \& Baumert, 2006).

In developing countries, limited studies are available about how teachers actually teach in the classroom and how this is related to teaching quality and learning outcomes (Heneveld \& Craig, 1996; Stephens, 1997). Within these limited studies, a "paradox" is mentioned in relation to mathematics classroom instruction in the Chinese context. This paradox stresses that a pedagogical culture that is based on "passive transmission" and "rote drilling" approaches nevertheless produces students who outperform their counterparts in the Western (Marton, Dall'Alba, \& Lai, 1993; Watkins \& Biggs, 2001). This rises our interesting on the question why status of the "not effective" teaching approaches actually contributes to the high learning performance. And, although most of the teacher in Chinese adopted the same pedagogical pattern, students achieved differently. That means, the pattern of "rote drilling approaches" or "passive transmission approaches" seems to work in the Chinese context; but, there might be additional qualities hidden in these instructional patterns.

While studies in 1990s revealed "the passive transmission" was effective for students' learning, the curriculum reform in Year 2001 encourages teachers to change their classroom teaching approaches from a "teacher-centered" to a "student-centered" approach (Zhong, 2006). This reform has raised a heavy debate in the Chinese context about the role of teachers and students in the instructional setting (Wang, 2004; Zhong, 2006). The debate is particularly heavy since Asian classes have found to be typically teacher-centered (see Schuh, 2004; Stevenson \& Stigler, 1992), The discussion is also fuelled due to the lack of empirical evidence that demonstrates - within the Chinese setting which approach has a differential positive and significant impact on performance.

All of these bring us to the general aims of the paper that present a qualitative/quantitative study, focusing on two key questions.

$>\quad$ Firstly, is it possible to identify particular instructional interaction patterns between teachers and students that contribute to students' mathematics performance?

$>$ Secondly, what patterns of instructional questioning can be identified and how are these related to mathematics performance?

\section{Theoretical Background}

Numerous studies have been conducted to explore operational variables that are related to classroom interaction and consistently are associated with student performance (Marzano, Pickering, \& Pollock, 2001). But research remains inconclusive about satisfactory solutions to grasp the nature of classroom interaction and to find (Reusser, 2001). 


\subsection{Classroom interaction and its' effect on mathematics performance}

Analysis on the classroom interaction aim at exploring the observable "sight structures" (Seidel \& Prenzel, 2006). A key assumption is that quality of classroom teaching and learning depends on the quality of the instructional interaction (Wang, Haertel, \& Walberg, 1993), Studies has shown how different interaction patterns have a clear effect on the packaging, presentation and (re)formulation of curriculum knowledge and related learning performance (Barnes \& Todd, 1995; Inagaki, Hatano, \& Morita, 1998).

Different frameworks exist to study classroom interaction. Some studies focus on the "function" of the classroom interaction: social, procedural, expository, explanatory and cognitive (Oliver \& McLoughlin, 1996). Other studies focus on the role of the actors in interaction: emitter, target, audience and residue members (Adams \& Biddle, 1970, p.20). The latter approach was already adopted by Chinese researchers in the middle of the 1990s. Chinese sociologists studied the interactions in elementary schools and identified a variety of prototypical interaction models (Wu, Wu, Cheng, \& Liu, 1995; Gao, Zhao, \& Liang, 2003). In the present paper, we also want to carry out the analysis by this framework. .

The Transmitter-Listener model refers to interaction patterns in which one teacher is the information transmitter and the whole class acts as listeners. Researchers state that this type of whole-class interaction does improve the effectiveness of the mathematics teaching process (Graham, Rowlands, Jennings, \& English, 1999; Reynolds \& Muijs, 1999).

While, The Target-target model refers to the public interaction between teacher and one a particular student or between the teacher and a specific group of students. This interaction is also labeled as dialogic inquiry (Wells, 1999) or discussion based teaching (Boaler, 2000). It is hypothesized to enable students to acquire ways of solving the questions. In this interaction model, the teacher plays an important role since he/she facilitates a high-quality student processing level or "math-talk" (Cobb \& Yackel, 1996). Teachers should - according to this model - especially intervene because they encourage students to verbalize their math thinking, to reconstruct solution processes and to resolve conflicting math ideas.

The Audience-player Model refers to the teachers being an audience for the work presented by single students or group of students. Since this model explicitly builds on student-student interactions, previous studies stresses that this small group work clearly gives rise to learning opportunities and is superior as compared to traditional classroom teaching (Yackel, Cobb, \& Wood, 1991). Students sharing their reasoning with one another is considered to be lead to cognitive activation and results in higher student performance (Redfield \& Rousseau, 1981). Sharing aloud their analytical ideas about a problem, the problem context, their reasoning, and their problem solving approaches is said to activate cognitive development. During the small group interaction, teachers are expected to scaffold the interaction (Webb, Nemer, \& Ing, 2006).This guarantees evaluative input that helps the groups and individual learners to improve and develop.

The Guide-learner model refers to teachers acting as a guide for their students who carry out individual work. Individual work is expected to be responsible for high levels of active thinking. Naturally, the effect will depend on the particular level of a students' engagement in the individual activity (Rimm-Kaufman, La Paro, Downer, \& Pianta, 2005; Stevenson \& Lee, 1995). This type of individual thinking "in private" is a very typical type of interaction in the Chinese educational context (Gao, Zhao, \& Liang, 2003).

A clear underlying dimension in the presentation of these interaction models is the extent to "teacher-centered" or "student-centered". In the "teacher-centered" models, the teacher controls the whole class and directs the learning processes to obtain a desired level of involvement and type of engagement (Wagner \& McCombs, 1995). In "student-centered" model, the activities are raised by the students. For example, students or groups of students determine the nature and organization of the content and classroom rules (McCombs \& Whisler, 1997). In general, the transmitter-listener and target-target model are in line with a teacher-centered perspective, while the audience-player and guide-learner model rather reflect a student-centered approach. 


\subsection{Teacher's questioning during the interaction and its effect on math performance}

Moving to the content level of instructional classroom interactions, the discourse between teacher and students is mainly shaped by the nature and quality of teacher questioning (Green \& Dixon, 1993; Nathan \& Knuth, 2003). The questioning behavior has already proven to be a promising direction. In the TIMSS 1995 video analysis study, it was found that compared to German lessons, students in Japanese classes reach a higher level cognitive activation due to the different nature of teacher questioning (Stigler et al., 1999). In many ways, the quality of instruction seems to depend on the quality of teacher questions and especially how they activate mathematical cognitive processes (Black, 2007; De Corte, 2004; Seidel \& Shavelson, 2007).

Several typologies of classroom questions are available in the literature. Some are especially geared to the domains of mathematics instruction (Chapman, Rosenshine, \& Meister, 1996; King, 1991). For instance, Perry, Vanderstoep and Yu (1993) constructed a questioning framework for grade one students in mathematics lessons. They distinguish between computation questions, rule recall questions, computing in context questions, make up a problem questions, problem-solving questions, identification questions, and conceptual knowledge questions. We build on the latter typology in the present study. The question typology can also be approached from another perspective by structuring them into three clusters in the present study.

A first cluster centers on questions about specific mathematical knowledge and skills, such as computations, rule recall, conceptual knowledge, computing in context and making up a problem. These questions vary depending on the particular mathematics sub- domain of the lessons. A second cluster of questions centers on mathematics learning processes, such as problem-solving strategies, and evaluation. Reviewing is used by the Chinese teachers and we will add this questioning type to the present study.

Recent research illuminates how these two clusters of questions impact cognitive learning processes due to an explicit activation of particular declarative or procedural knowledge (Daniels, 2001; Vygotsky, 1978). First, due to the teacher questions, student progress from concrete to more abstract ideas. They rethink their assumptions, develop clear hypotheses, and make efforts to adapt and as such (re)construct new mathematical knowledge by the teachers' questions (Hinrichsen \& Jarrett, 1999). Secondly, classroom questioning dialogue also focuses on the logics of mathematical thinking when that is needed to go beyond what is currently known. This is mirrored in students being asked to reflect on differing solution strategies (Edwards \& Mercer, 1987). Thus, on the one hand students construct new declarative and procedural knowledge, and on the other hand students develop the methods for learning mathematics (De Corte, 2003; Kramarski, Mevarech, \& Arami, 2002).

A third cluster of questions is related to classroom management, such as identification. These questions help to direct student attention. Though this type of questions can very often been found during instructional activities, research stressed that questions that rather fostered active academic involvement, are more beneficial for classroom performance as compared to questions that emphasize classroom management (Brophy \& Good, 1986; Doyle, 1977). On the base of the theoretical and empirical findings about interaction models and the question typology, a study has been set up that links classroom interaction to mathematics learning performance. Next to data about mathematics performance, the study builds on the coding of video recordings of actual mathematics classroom sessions.

\section{Research design}

\subsection{Participants}

During year 2008-2009, considering the rural and urban, more than ten thousand students and hundreds of teachers from twenty schools in five regions with different GDP level participated in a project (Zhao, Valcke, Desoete, Verhaeghe, \& Xu, 2011). Teachers were asked to do the further study and nine teachers and their classes (in total 601 students) in either a rural or an urban region agreed for the video analysis. During school year 
Does teacher-centered teaching contribute to students' performance in primary school? A video analysis

2008-2009, mathematic lessons of these nine mathematics teachers were videotaped. These videotaped lessons were analyzed in view of the present study. Each mathematics lesson lasted between 35-45 minutes. Forty minutes is the average duration of a lesson in Chinese primary schools. But teachers can extend a lesson with a few more minutes during the lesson pause. In each of the participating class, one teacher did work with between 43 and 98 students $(M \approx 66, S D \approx 19)$.

\subsection{Methods}

A mixed-method approach was adopted, combining both qualitative and quantitative methods to study the impact of the particular teaching approaches and developing a picture that was respectful for the particular culture context (Morse, 2003). Our analysis framework consisted of two approaches towards the video analysis to interpret classroom instructional processes. The first approach helped to identify the particular nature of the interaction patterns in the mathematics lessons. The second approach centered on the interaction content, especially on teachers' questioning. In the context of both approaches, the same dependent variable was considered: mathematics performance.

Dependent Variable: Mathematics performance - A newly developed, standardized instrument was used to measure the students' mathematics performance (Zhao et al., 2011). This test covers the three mathematics domains of the 2001 curriculum syllabus (Ministry of Education, 2001) and focuses on twelve sub-domains (Desoete \& Roeyers, 2005; Nunes, Bryant, Evans, Bell, Gardner, 2007; Zimmermann \& Cunningham, 1991). There are 10,959 primary school students involved from twenty schools in five Chinese provinces with different economic levels. Internal consistency (Cronbach's $\alpha$ ) values of the grade level tests ranges from 0.93 to 0.96 . From the dataset, nine teachers and their 601 students were selected in view of the present study. Considering the fact the classes were from different school grades, the student scores were standardized within their grade in order to determine student's relative position.

Independent variable: controlling for the school variance - The aggregated variable of the school means for the mathematics performance is used as the controlling variable to decrease the variance of the school resources and situation for the effect of the classroom teaching (Greenwald, Hedges, \& Laine, 1996). Independent variable 1: Interaction patterns. As the first independent variable which is expected to influence math performance, the study focused on the nature of interaction patterns between teachers and students. The interaction typology was based - as discussed earlier - on the approaches adopted in previous studies (Adams \& Biddle, 1970; Belleck, 1967; Gao, Zhao, \& Liang, 2003). In view of the coding, the video recordings were split up into units of 10 seconds per unit and coded according to a procedure described below. Table 1 gives an overview of the coding categories.

\section{Table 1}

Interaction patterns in the mathematics classroom

\begin{tabular}{lll}
\hline \multicolumn{1}{c}{ Interaction } & \multicolumn{1}{c}{ Interaction sub-type } & \multicolumn{1}{c}{ Examples } \\
\hline $\begin{array}{l}\text { Transmitter - Listener } \\
\text { Target - Target }\end{array}$ & $\begin{array}{l}\text { One Teacher - whole class } \\
\text { One Teacher - one student }\end{array}$ & $\begin{array}{l}\text { Direct instruction } \\
\text { Teacher asks questions or reacts to student } \\
\text { questions } \\
\text { Teacher evaluates students or manages } \\
\text { classroom } \\
\text { Teacher asks questions or reacts to student } \\
\text { questions }\end{array}$ \\
& One Teacher - group of students \\
& $\begin{array}{l}\text { Teacher evaluates students or manages the } \\
\text { classroom }\end{array}$ \\
Audience - Player & Students - students in public & $\begin{array}{l}\text { Students present, explain reasons } \\
\text { Students discuss with partner }\end{array}$ \\
Guide - Learner & Individual thinking in private & Students exercise with the help of the teacher \\
\hline
\end{tabular}

Independent variable 2: Teacher question types. The second part of the video analysis focused on teacher 
question types. Based on the previous studies (Perry, VanderStoep, \& Yu, 1993), eight question categories were identified (See Table 2). In order to balance question types in relation to math content and the specific lesson setting and the total number of questions, the percentage of each question type was used as a measure in the study. The following equation was used to calculate the relative proportions:

$$
\text { Percentage of each categories }=\frac{\text { Times of this categories in each class }}{\text { The sume of questioning in this class }}
$$

Table 2

Interaction patterns of the mathematics classroom

\begin{tabular}{|c|c|c|}
\hline & Question type & Example \\
\hline \multirow[t]{5}{*}{ Cluster 1} & 1. computation/rote recall & $7+3$ equals? \\
\hline & 2. rule recall & What is the rule for two-digit addition? \\
\hline & 3. conceptual knowledge & Why do you use subtraction for this problem? \\
\hline & 4. computing in context & $\begin{array}{l}\text { There are } 30 \text { pieces of red folding paper, } 20 \text { green. How many are } \\
\text { there altogether? }\end{array}$ \\
\hline & 5. make up a problem & Create a problem that leads to the equation $8-3-2=3$ \\
\hline \multirow[t]{3}{*}{ Cluster 2} & 6. review & What did you learn in today's lesson? \\
\hline & 7. problem-solving strategies & How did you arrive at this answer? \\
\hline & 8. evaluation & Do others agree with the answer? Why? \\
\hline Cluster 3 & 9. identification & $\begin{array}{l}\text { Identify what is known when the teacher is directing a students' } \\
\text { attention to important properties of a problem }\end{array}$ \\
\hline
\end{tabular}

\subsection{Coding procedure}

The coding was based on the following procedure to ensure the validity: Firstly, all video sequences were transcribed by the authors, taking care to note both verbal and non-verbal behaviors. Transcript conventions were adapted from approaches by Jefferson (2004). Secondly, two observers were trained and independently coded the lessons. There are two coding patterns. Firstly, the transcripts of every 10 second interval were approached as the unit for coding for interaction between teacher and students. Secondly, one code was given to each teacher questions. The software program NVivo 8.0 was used to carry out the coding of both the classroom interaction and the question types. An inter-observer reliability of $>.80$ was established (=Total agreements/Total observations).

\subsection{Statistical analysis}

Since the coded observation data are nested at two levels - class level and student level - a multilevel regression analysis was adopted. Calculations were carried out with the software program MPlus 5.0. In addition, the analysis was also carried out on the base of a multi-level analysis considering the nested nature of the data (students, classes).

\section{Results}

\subsection{Classroom interaction and mathematics performance}

Results reveal that the interaction of one teacher-whole class $(M=15.33, S D=3.76)$ and one teacher and individual student $(M=12.91, S D=6.85)$ are the most popular in mathematics classes in primary schools. The results also show that interaction of student and student in public $(M=2.09, S D=4.62)$ appears to be the third strategy used in mathematics classes. Teachers interacting with the whole class occupy about $38.66 \%$ of the time, while the teachers interacting with individual students or with a group of students occupy $32.54 \%$ and $.93 \%$ of the time. The Transmitter-Listener and Target-Target interaction type that both reflect a teacher-centered approach, determine over $70 \%$ of the lesson time. 
Does teacher-centered teaching contribute to students' performance in primary school? A video analysis

Prior to the calculation, correlations between independent and dependent variables were checked (Bonferroni correction was applied). Mathematics performance is significantly correlated with the different independent variables.

In a first step, in order to control for the impact at the school level, we add the school mean in mathematics performance to the null model. Compared with the null model, the variance at classroom level reduces from .501 to .093 (See Table 3). In a second step, we add - step-by-step - all independent variables to the model: transmission-listener, target-target, audience-player and guide-learner. The results show that the interaction type "one teacher-one student" is an important predictor for students' mathematics performance. The variance at the class level drops from .093 to .073 . Next, the interaction types "student-student in public" and "in private" are added to the model. The AIC and BIC (adjusted to the sample size) drop to the lowest coefficients of 1086.545 and 1095.112 respectively, implying this final model is most optimal. The interaction types "student-student in public" and "in private" are as such the best predictors for mathematics performance with an effect size of .356 and -.256. Except for the school means of math performance, up to $76.34 \%$ of the variance at class level is explained by these three types of instructional interaction. The results repeatedly show teacher-centered approaches improve student performance while student-centered approaches (e.g., student-student in private) decrease student performance.

\subsection{Teacher's questions and mathematics performance}

As could be derived from the former section, teacher input occupied most of the lesson time. In this section, we focus on teacher's questioning behavior and its impact on mathematics performance in the classroom. Questioning of problem solving strategies occupied $30.16 \%$ of the total frequencies. The following is identification and evaluation which occupied $26.61 \%$ and $11.53 \%$ of the whole frequencies.

Prior to the calculation of the stepwise regression analysis, correlation analysis indicates that independent and dependent variables are significantly correlated with one another. The results of the multilevel analysis are presented in the Table 3. Building on a multilevel analysis approach, after adding the school means mathematics performance to the null model, all teacher question types are included step by step to the model. Rule recall questions have a negative effect on mathematics performance. However, problem solving and the evaluation questions have a positive effect on mathematics performance. The variance at class level drops from .093 to .005 in the final model (AIC and BIC - adjusted by the sample size - are 1080.479 and 1090.270 respectively). Compared to Model 1, except for the school mean of math performance, $94.6 \%$ of the variance at class level is explained by the question types "rule recall"," problem solving" and "evaluation". When controlling for school diversity on the base of the school mean performance, it is clear that the more questions asked building on problem solving and evaluation, the higher the mathematics performance of the students.

\section{Discussion}

\subsection{Teacher-centered or students-centered? Who should direct the instructional processes?}

From Year 2001, the Ministry of Education (MOE) in China tried to change the teaching and learning approaches and encourage the teachers to adopt innovative instructional strategies, (such as small group collaborative learning) instead of the dominant traditional approach labeled as a direct instruction approach. This explicit call from the educational authorities caused a strong debate and doubt as to the relevance of innovative instructional models. Although classroom interaction is dominated by the teacher and a whole-class instructional approach is adopted as a mainstream modus in Chinese mathematics lessons (Wang, 2011), the debate indicates that this approach is not in itself a negative way of setting up instruction. Though the latter approach is often labeled as "passive transmission", actual teacher behavior is open for student input. Both the teaching approaches propagated by the MOE and the traditional teaching approaches seem to be adopted by the teachers and mixed into the mathematics teaching and learning context. 
Zhao, N., Valcke, M., Annemie, D., Sang, G., \& Zhu, C.

Table 3

Multilevel analysis on effect of interaction and questioning on the students' performance

\begin{tabular}{|c|c|c|c|c|c|c|c|c|}
\hline Predictor & M0 & M1 & M2 & M3 & ES & M4 & M5 & $\mathrm{ES}$ \\
\hline \multicolumn{9}{|l|}{ FIXED } \\
\hline Intercept & $\begin{array}{r}.223 \\
(.237)\end{array}$ & $\begin{array}{r}.078 \\
(.111)\end{array}$ & $\begin{array}{c}-.203 \\
(.148)\end{array}$ & $\begin{array}{r}-.032 \\
(.256)\end{array}$ & - & $\begin{array}{r}.165 \\
(.110)\end{array}$ & $\begin{array}{r}-.914 \\
(.269)\end{array}$ & 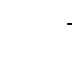 \\
\hline $\begin{array}{l}\text { School mean of math } \\
\text { performance }\end{array}$ & & $\begin{array}{r}.882 \\
(.118)\end{array}$ & $\begin{array}{r}.866 \\
(.102)\end{array}$ & $\begin{array}{r}.601 \\
(.102)\end{array}$ & .457 & $\begin{array}{r}.943 \\
(.129)\end{array}$ & $\begin{array}{r}.959 \\
(.047)\end{array}$ & .729 \\
\hline One teacher-one student & & & $\begin{array}{r}.022 \\
(.010)\end{array}$ & $\begin{array}{r}.030 \\
(.015)\end{array}$ & .216 & & & \\
\hline Student-student in public & & & & $\begin{array}{r}.078 \\
(.002)\end{array}$ & .356 & & & \\
\hline Student-student in private & & & & $\begin{array}{l}-.074 \\
(021) \\
\end{array}$ & -.256 & & & \\
\hline Rule & & & & & & $\begin{array}{r}-.099 \\
(.032)\end{array}$ & $\begin{array}{r}-.093 \\
(.011)\end{array}$ & -.009 \\
\hline Problem solving & & & & & & & $\begin{array}{r}.014 \\
(.004)\end{array}$ & .002 \\
\hline Evaluation & & & & & & & $\begin{array}{r}.062 \\
(.008) \\
\end{array}$ & .005 \\
\hline \multicolumn{9}{|l|}{ Random Part } \\
\hline Level: Class & & & & & & & & \\
\hline$\sigma_{\mathrm{W}}^{\mathrm{s}}$ & $\begin{array}{r}.501 \\
(.141)\end{array}$ & $\begin{array}{r}.093 \\
(.039)\end{array}$ & $\begin{array}{r}.073 \\
(.037)\end{array}$ & $\begin{array}{r}.022 \\
(.012)\end{array}$ & & $\begin{array}{r}.072 \\
(.031)\end{array}$ & $\begin{array}{r}.005 \\
(.007)\end{array}$ & \\
\hline \multicolumn{9}{|l|}{ Level: Student } \\
\hline$\sigma_{0:}^{2}$ & $\begin{array}{r}.340 \\
(.044)\end{array}$ & $\begin{array}{r}.340 \\
(.044)\end{array}$ & $\begin{array}{r}.340 \\
(.044)\end{array}$ & $\begin{array}{r}.340 \\
(.044)\end{array}$ & & $\begin{array}{r}.341 \\
(.044)\end{array}$ & $\begin{array}{r}.341 \\
(.044)\end{array}$ & \\
\hline CFI & 1.000 & 1.000 & 1.000 & 1.000 & & 1.000 & 1.000 & \\
\hline TLI & 1.000 & 1.000 & 1.000 & 1.000 & & 1.000 & 1.000 & \\
\hline AIC & 1104.905 & 1092.168 & 1092.125 & 1086.545 & & 1091.949 & 1080.479 & \\
\hline Sample-size adjusted BIC & 1108.577 & 1097.064 & 1098.244 & 1095.112 & & 1098.068 & 1090.270 & \\
\hline Log liikelihood & -549.483 & -542.084 & -541.062 & -536.273 & & -540.974 & -532.240 & \\
\hline Chi-square & 0 & 14.26 & 18.88 & 33.542 & & 21.996 & 48.508 & \\
\hline$d f$ & 0 & 1 & 2 & 4 & & 2 & 5 & \\
\hline$p$ & 1.000 & .0002 & .0001 & .0000 & & .000 & .000 & \\
\hline
\end{tabular}

In the present study, it nevertheless revealed that teachers dominate the Chinese classroom interaction. This is in line with the findings of previous studies (Stevenson \& Lee, 1995; Lim, 2007). The results show that teacher-one student interaction in public and student-student interaction in public play a positive role in attaining mathematics performance. In contrast, the student-student interaction in private reveals a negative impact on mathematics performance. Interactions between small groups of students in private also provide learning opportunities for mathematics (Yackel, Cobb, \& Wood, 1991). The question now arises why these particular interaction pattern have this particular impact in the Chinese context?

Interactions types have specific advantages or disadvantages under different conditions (Tan, Sharan \& Lee, 2007). On the one hand, interactions roused by the teacher seem to have a positive influence in classes with a larger class size. Large classes are a common feature in the Chinese context (where classes up to 79 pupils are listed). Teacher-centered interaction seems to support student interaction from a socio-cultural theory perspective (John-Steiner \& Mahn, 1996). As beginning mathematics learners, primary school students can hardly depend on each other's experience and need guided participation (Rogoff, 1990). Teachers function as such in the zone of proximate development (ZPD). They demonstrate problem solving strategies and apply questioning, supported with visual representations and verbalizations (Gersten, Chard, Jayanthi, Baker, Morphy et al., 2009). After fostering student-student interaction in public, teachers direct students' individual reflection towards their problem-solving strategies. For example,

Teacher: Do you have any questions about this presentation?

Students chorus: No. 
Does teacher-centered teaching contribute to students' performance in primary school? A video analysis

Teacher: No? Really? Then, I have a question for student 1 and student 2. I want to ask you. How do you divide the parallelogram into two triangles? (Teacher holds up the paper parallelogram. Student 1 and student 2 point at the diagonal and say nothing.)

Teacher: OK. Look at this? The paper parallelogram? (Teacher points at the diagonal in the parallelogram.) I cut the parallelogram into two triangles along the diagonal of the parallelogram.

Teacher: Come here and stick your triangles on the blackboard. Come.

(Retrieved from transcripts 624500-Time zone 111-113)

In this case, after the student-student interaction in public, the teacher checks whether the students understand the students' presentation. Though students say "in chorus" for understanding, teachers explicitly check whether individual students understand this particular insight. Often, after the interaction in public, teachers also give individual remarks and invoke student reflection on the discourse. In the latter case, since student 1 and student 2 couldn't explain the approach by using a mathematics language, the teacher supports them by presenting to the concept of "diagonal". Our findings indicate that this type of teacher-one student and student-student in public interaction have a positive impact on performance; even though they are rather teachers-centered.

Student-student in private interaction is out of the control of the teacher. Much depends on the quality of the student involvement during the interaction (Christle \& Schuster, 2003). Mere interaction is not valuable in itself.

And the present results raise the interesting question how to deal with the relationship between traditional teaching approaches and new teaching approaches. In the Chinese context, student-centered interaction is a new teaching strategy. Since 1980s, studies about student-centered interaction involving small groups of students indicate this improves higher order thinking and can lead to higher achievement (Sharan \& Ackerman, 1980). However, there is no clear relationship between the duration of the student-centered interaction and the quantity and quality of students' engagement. The results clearly indicate that attention should be paid to teaching training in the context of the curriculum reform and to set up additional research to monitor the educational impact of the adoption of innovative instructional strategies. The lack of an evidence-base makes teachers reluctant to embrace the new pedagogies in the Chinese context.

\subsection{Teacher questions and the scaffolding of students' mathematical thinking}

Since teacher-centered approaches seem to be related to higher mathematics performance, the next research aim focused on how teacher questions scaffold students' mathematical thinking. The impact of questioning on performance has been a recurrent research theme during the past decades (Gall, 1970). Evaluation and problem-solving questions seem to have of positive impact on performance; while others question types have no impacts or even a negative influence.

There are several ways to explain the particular impact of these question types. First, teachers adopting problem solving related questions ask their students to make explicit their procedural thinking and how they reach the results. At this stage, experienced teachers can emphasize important points of the mathematics content. The following is the example about the hierarchy in the calculation of arithmetic operations:

Teacher: For this operation, who knows which part we should calculate first? The addition or the subtraction? Student 58 .

Student 58: I think we should first calculate the subtraction and then addition.

Teacher: Ok, take your seat please. See if we put addition at the front, we should first calculate the addition. If we have subtraction t the front, then ... 
Zhao, N., Valcke, M., Annemie, D., Sang, G., \& Zhu, C.

Student chorus: We should calculate the subtraction first.

Teacher: Ok, just like we stand in a line: the one who is at the front, then ....

Student chorus: We should calculate it first.

(Retrieved from the transcripts 721100-Time zone 165-167)

In the above example, the teacher catches the important points of the mathematics calculation process and uses a metaphor to construct the mental image of "order in calculations" for the students. The present research results are in line with previous studies. The teacher makes use of the questions that monitor and check students' understanding (Garza, 2009).

Second, teachers' evaluation questions also have a clear impact on performance. The teacher asks in this way that students evaluate their own behavior. This seems to be one of the best strategies to extract from the students information about their own understanding of the problems or tasks. The questions also give students an opportunity to reflect on their own and their peers' cognitive processes. And, we can return to the transcripts 624500-Time zone 111-113

In this example, the teacher asks the students to reflect on the answer. This is followed by another question about the problem-solving process in which students have to verbalize their own cognitive processes ("How do you divide the parallelogram into two triangles?"). Evaluation questions and problem-solving questions are combined during the lesson. Teachers who adopt questions invoke dynamic assessment (Swanson \& Lussier, 2001) and influence performance in a positive way.

\section{Conclusions, limitations and directions for future research}

Compared to the previous studies, on the one hand, the present article constructed the two independent models on the teaching and learning performance. Most of the studies focus on the interaction between teacher and students, such as TIMSS. And their video only reveals the difference patterns between countries but not the deeply reasons within one countries. The present study reveals that within the similar patterns in the same culture, what kind of teachers' activities contribute to the students' learning performance. On the other hand, most of the previous studies focus on the qualitative analysis. The present study combines quantitative and qualitative approaches to develop a richer picture of the relationship between instructional processes and mathematics performance. This gives us a better understanding what works the students' performance in Chinese context. Moreover, most of the previous studies only used multiple regressions analysis without considering the nested data. In the present study, the multilevel analysis was used to analyze the nested data and the combination effect of environmental variables (such as school level, teacher quality) was controlled by adding the school level students' performance.

And, the present study gives some implications for teachers and teacher educators. Firstly, teacher-centered instructional approaches seem to be an effective approach for mathematics learning in China. This gives an implication that we should balance between student- and teacher-centered approaches in the classroom. Each of the student's collaborative activities should be guided and organized by the teachers. Secondly, the teachers' evaluation and problem-solving questioning support to develop the students' mathematical thinking. The teachers training should focus on the teachers' ability of evaluation and problem-solving. In addition, the results also invoke a discussion about the need for additional teacher training at pre-service and in-service level, to make teacher better acquainted with alternative instructional interaction approaches.

However, there were some limitations. First, we have to note that our study of instructional effectiveness only centered on mathematics performance, and did not include other performance domains, such as language, sciences. In addition, no attention was paid to critical mediating variables, such as teacher's beliefs on the instruction (Ampadu, 2014). Secondly, the results are gathered from 9 teachers and their classes and a limited 
Does teacher-centered teaching contribute to students' performance in primary school? A video analysis

number of lesson periods. The results could reflect the particulars of the present sample and be less applicable to the population. Additional studies that involve a larger number of teachers and classes during a longer period of time, in view of being able to generalize the results. Third, in our analysis approach we only focused on two levels in the interaction. In large-scale studies students should be studied in their classroom setting and within their schools to be able to take into account processes and variables related to school policies or school culture.

Future studies also need to pay attention to the social attitudes and skills of students. Collaborative learning research has underpinned the need to develop social interaction skills in learners in view of effective learning (Johnson \& Johnson, 1996; Slavin, 1996). The adoption of innovative instructional approach cannot neglect next to teacher development - the additional development of generic competences in learners, such as learning to interact, learning to report, setting personal objectives, etc.

\section{References:}

Adams, R. S., \& Biddle, B. J. (1970). Realities of teaching: Explorations with video tape. New York: Holt, Rinehart, and Winston.

Ampadu, E. (2014). Implementing a new mathematics curriculum: mathematics teachers' beliefs and practices. International Journal of Research Studies in Education, 3(1), 79-90. http://dx.doi.org/10.5861/ijrse.2013.562

Barnes, D., \& Todd, F. (1995). Communication and learning revisited: Making meaning through talk. Portsmouth, NH: Boynton/Cook Publisher Inc.

Belleck, A. A. (1967). The Language of the classroom. New York: Teachers College Press.

Black, L. (2007). Analysing cultural models in socio-cultural discourse analysis. International Journal of Educational Research, 46(1-2), 20-30. http://dx.doi.org/10.1016/j.ijer.2007.07.003

Boaler, J. (2000). Mathematics from another world: Traditional communities and the alienation of learners. Journal of Mathematical Behavior, 18(4), 1-19. http://dx.doi.org/10.1016/S0732-3123(00)00026-2

Brophy, J., \& Good, T. L. (1986). Teacher behavior and student achievement. In M. C. Wittrock (Ed.). Handbook of research on teaching ( $3^{\text {rd }}$ ed., pp. 328-375). New York: Simon \& Schuster.

Chapman, S., Rosenshine, B., \& Meister, C. (1996). Teaching students to generate questions: a review of the intervention studies. Review of Educational Research, 66(2), 181-221. http://dx.doi.org/10.3102/00346543066002181

Christle, C. A., \& Schuster, J. W. (2003). Effects of using response cards on student participation, academic achievement, and on-task behavior during whole-class, math instruction. Journal of Behavioral Education, 12(3), 147-165. http://dx.doi.org/10.1023/A:1025577410113

Cobb, P., \& Yackel, E. (1996). Constructivist, emergent, and sociocultural perspectives in the context of developmental research. Educational Psychologist, 31(3-4), 175-190. http://dx.doi.org/10.1080/00461520.1996.9653265

Daniels, H. (2001). Vygotsky and pedagogy. London: Routledge.

De Corte, E. (2003). Designing learning environments that foster the productive use of acquired knowledge and skills. In E. De Corte, L. Verschaffel, N. Entwistle, \& J. J. G. van Merrienboer (Eds.). Powerful learning enviornments: unravelling basic components and dimensions (pp. 21-33). Amsterdam: Pergamon.

De Corte, E. (2004). Mainstreams and perspectives in research on learning (mathematics) from instruction. Applied psychology: An International Review, 53(2), 279-310. http://dx.doi.org/10.1111/j.1464-0597.2004.00172.x

Desoete, A., \& Roeyers, H. (2005). Cognitive skills in mathematical problem solving in grade 3. British Journal of Educational Psychology, 75(1), 119-138. http://dx.doi.org/10.1348/000709904X22287

Doyle, W. (1977). Paradigms for research on teacher effectiveness. In L. S. Shulman (Ed.). Review of research in education (Vol. 5, pp. 163-198). Washington, DC: American Educational Research Association.

Edwards, D., \& Mercer, N. (1987). Common knowledge: The development of understanding in the classroom. London: Routledge. 
Zhao, N., Valcke, M., Annemie, D., Sang, G., \& Zhu, C.

Gall, M. D. (1970). The use of the questions in teaching. Review of educational research, 40(5), 707-721. http://dx.doi.org/10.3102/00346543040005707

Gao, L. B., Zhao, N.N., \& Liang, C. F. (2003). The studies on the observation on classroom interaction in primary school [Ketang guancha jiaowang yanjiu]. In Educational Science Research [jiaoyu kexue yanjiu]. 6, 25-28.

Garza, R. (2009). Latino and white high school students' perceptions of caring behaviors: Are we culturally responsive to our students? Urban Education, 44(3), 297-321. http://dx.doi.org/10.1177/0042085908318714

Gersten, R., Chard, D. J., Jayanthi, M., Baker, S. K., Morphy, P., \& Flojo, J. (2009). Mathematics instruction for students with learning disabilities: a meta-analysis of instructional components. Review of Educational Research, 79(3), 1202-1242. http://dx.doi.org/10.3102/0034654309334431

Graham, T., Rowlands, S., Jennings, S., \& English, J. (1999). Towards whole-class interactive teaching. Teaching Mathematics and Its Application, 18(2), 50-60. http://dx.doi.org/10.1093/teamat/18.2.50

Green, J., \& Dixon, C. (1993). Introduction to special issue. Talking knowledge into being: Discursive and social practices in classroom. Linguistics and Education. 5(3-4), 231-239. http://dx.doi.org/10.1016/0898-5898(93)90001-Q

Greenwald, R., Hedges, L. V., \& Laine, R. D. (1996). The effect of school resources on student achievement. Review of Educational Research, 66(3), 361-396. http://dx.doi.org/10.3102/00346543066003361

Heneveld, W., \& Craig, H. (1996). School count: World Bank project designs and the quality of primary education in sub-Ssharan Africa. Washington, DC: World Bank. http://dx.doi.org/10.1596/0-8213-3460-3

Hiebert, J., Gallimore, R., Garnier, H., Givven, K. B., Hollingsworth, H., Jacobs, J., Chui, A. M. Y., Wearne, D., Smith, M., Manaster, A., Tseng, E., Etterbeek, W., Manaster, C., Gonzales, P., \& Stigler, J. W. (2003). Teaching mathematics in seven countries: Results from the TIMSS 1999 Video Study. Washington, D.C.: U.S. Department of Education, National Center for Education Statistics.

Hinrichsen, J., \& Jarrett, D. (1999) Science inquiry for the classroom: A literature review. Oregon: Northwest Regional Educational Laboratory.

Hugener, I., Pauli, C., Reusser, K., Lipowsky, F., Rakoczy K., \& Klieme, E. (2009). Teaching patterns and learning quality in Swiss and German mathematics lessons. Learning and Instruction, 19(1), 66-78. http://dx.doi.org/10.1016/j.learninstruc.2008.02.001

Inagaki, K., Hatano, G., \& Moritas, E. (1998), Construction of mathematical knowledge through whole class discussion, Learning and Instruction, 8(6), 503-526. http://dx.doi.org/10.1016/S0959-4752(98)00032-2

Jefferson, G. (2004). Glossary of transcript symbols with an introduction. In G. H. Lerner (Ed.), Conversation analysis: Studies from the first generation (pp. 13-31). Amsterdam and Philadelphia: John Benjamins.

Johnson, D. W., \& Johnson, R.T. (1996). Cooperation and the use of technology. In D. Jonassen (Ed.). Handbook of research for educational communications and technology (pp.1017-1044). New York: Simon and Schuster MacMillan.

John-Steiner, V., \& Mahn, H. (1996). Sociocultural approaches to learning and development: A Vygotskian Framework. Educational Psychologist, 31(3/4), 191-206. http://dx.doi.org/10.1080/00461520.1996.9653266

King, A. (1991). Effects of training in strategic questioning on Children's problem-solving performance. Journal of Educational Psychology, 83(3), 307-317. http://dx.doi.org/10.1037/0022-0663.83.3.307

Kramarski, B., Mevarech, Z. R., \& Arami, M. (2002). The effects of metacognitive instruction on solving mathematical authentic tasks. Educational Studies in Mathematics, 49(2), 225-250. http://dx.doi.org/10.1023/A:1016282811724

Kunter, M., \& Baumert, J., (2006). Linking the TIMSS to research on learning and instruction: a reanalysis of the German TIMSS and TIMSS video data. In S. J. Howie, \& T. Plomp (Eds.), Learning mathematics and science: Lessons learned from TIMSS (pp. 335-351). London: Routledge Falmer.

Lim, C. S. (2007). Characteristics of Mathematics Teaching in Shanghai, China: Through the lens of a Malaysian. Mathematics Education Research Journal, 19(1), 77-89. http://dx.doi.org/10.1007/BF03217450 
Does teacher-centered teaching contribute to students' performance in primary school? A video analysis

Marton, F., Dall' Alba, G., \& Lai, K. T. (1993). The paradox of the Chinese learner (Occasional Paper 93.1). Melbourne, Australia: Educational Research and Development Unit, Royal Melbourne Institute of Technology.

Marzano, R. J., Pickering, D. J., \& Pollock, J. E. (2001). Classroom instruction that works: Research-based strategies for increasing student achievement. Alexandria, VA: Association for Supervision and Curriculum Development.

McCombs, B. L., \& Whisler, J. S. (1997). The learner-centered classroom and school: Strategies for increasing student motivation and achievement. San Francisco: Jossey-Bass.

Ministry of Education in P.R. China. (2001). Mathematics Curriculum Standards in the Phase of Full-time Compulsory Education - Experimental Manuscript [quanrizhi yiwu jiaoyujieduan shuxue kecheng biaozhun]. Beijing: Beijing Normal University Publisher.

Morse, J. M. (2003). Principles of mixed methods and multimethod research design. In A. Taskhkkori \& C. Teddlie (Eds.), Handbook of mixed methods in social and behavioral research (pp. 189-208). Thousand Oaks: Sage Publications.

Nathan, M. J., \& Knuth, E. J. (2003). A study of whole classroom mathematical discourse and teacher change. Cognition and Instruction, 21(2), 175-207. http://dx.doi.org/10.1207/S1532690XCI2102_03

Nunes, T., Bryant, P., Evans, D., Bell, D., Gardner, S., Gardner, A., \& Carraher, J. (2007). The contribution of logical reasoning to the learning of mathematics in primary school. British Journal of Development Psychology, 25(1), 147-166. http://dx.doi.org/10.1348/026151006X153127

Oliver, R., \& McLaughlin, C. (1996). An investigation of the nature and forms of interaction in live interactive television. Retrieved from ERIC Database (ED 396738).

Perry, M., VanderStoep, S. W., \& Yu, S. L. (1993). Asking questions in first-grade mathematics classes: Potential influences on mathematical thought. Journal of Educational Psychology, 85(1), 31-40. http://dx.doi.org/10.1037/0022-0663.85.1.31

Redfield, D. L., \& Rousseau, E. W. (1981). A meta-analysis of experimental research on teacher questioning behavior. Review of Educational Research, 51(2), 237-245. http://dx.doi.org/10.3102/00346543051002237

Reusser, K. (2001, September 1). Bridging instruction to learning - where we come from and where we need to go: A research strategy and its implementation in a cross-cultural video survey in Switzerland. Paper presented at the $9^{\text {th }}$ EARLI conference, Fribourg, Switzerland.

Reynolds, D., \& Muijs, D. (1999). Numeracy matters: contemporary policy issues in the teaching of mathematics. In I. Thompson (Ed.). Issues in teaching numeracy in primary schools. Buckingham: Open University Press.

Rimm-Kaufman, S. E., La Paro, K. M., Downer, J. T., \& Pianta, R. C. (2005). The contribution of classroom setting and quality of instruction to children's behavior in the kindergarten classroom. Elementary School Journal, 105(4), 377-394. http://dx.doi.org/10.1086/429948

Rogoff, B. (1990). Apprenticeship in thinking. New York: Oxford University Press.

Sharan, S., \& Achkerman, Z. (1980). Academic achievement of elementary school children in small-group versus whole-class instruction. Journal of experimental education, 48(2), 125-129.

Schuh, K. L. (2004). Learner-centered principles in teacher-centered practices? Teaching and Teacher Education, 20(8), 833-846. http://dx.doi.org/10.1016/j.tate.2004.09.008

Seidel, T., \& Prenzel, M. (2006). Stability of teaching patterns in physics instruction: Findings from a video study. Learning and Instruction, 16(3), 228-240. http://dx.doi.org/10.1016/j.learninstruc.2006.03.002

Seidel, T., \& Shavelson, R. J. (2007). Teaching effectiveness research in the past decade: The role of theory and research design in disentangling meta-analysis research. Review of Educational Research, 77, 454-499. http://dx.doi.org/10.3102/0034654307310317

Slavin, R. E. (1996). Research on cooperative learning and achievement: What we know, what we need to know. Contemporary Educational Psychology, 21(1), 43-69. http://dx.doi.org/10.1006/ceps.1996.0004

Stephens, D. (1997). Quality of primary education. In K. Watson, C. Modgil, \& S. Modgil (Eds.), Educational dilemmas: Debate and diversity, quality in education (Vol. 4, pp.51-64). London, Cassell. 
Zhao, N., Valcke, M., Annemie, D., Sang, G., \& Zhu, C.

Stevenson, H. W., \& Lee, S. Y. (1995). The East Asian version of whole-class teaching. Education Policy, 9(2), 152-168. http://dx.doi.org/10.1177/0895904895009002004

Stevenson, H. W., \& Stigler, J. W. (1992). The learning gap: The best ideas from world's teachers for improving education in classroom. New York: Free Press.

Stigler, J., Gonzales, P., Kawanaka, T., Knoll, S., \& Serrano, A. (1999). The TIMSS videotape classroom study. Methods and findings from an exploratory research project on eighth-grade mathematics instruction in Germany, Japan and the United States. Washington, DC: US Department of Education.

Swanson, H. L., \& Lussier, C. M. (2001). A selective synthesis of the experimental literature on dynamic assessment. Review of Educational Research, 71(2), 321-363. http://dx.doi.org/10.3102/00346543071002321

Tan, I. G. C., Sharan, S., \& Lee, C. K. E. (2007). Group investigation effects on achievement, motivation, and perceptions of students in Singapore. The Journal of Educational Research, 100(3), 142-154. http://dx.doi.org/10.3200/JOER.100.3.142-154

Vygotsky, L. S. (1978). Mind in society, Cambridge, MA: Harvard University Press.

Wagner, E. D., \& McCombs, B. L. (1995). Learner centered psychological principles in practice: designs for distance education. Educational Technology, 35(2), 32-35.

Wang, C. (2004). A critical reflection on the thought of "despising knowledge" in Chinese basic education [Renzhen duidai qingshi zhishi de jiaoyu sichao: zaiping you yingshi jiaoyu xiang suzhi jiaoyu zhuangui tifa de taolun]. Peking University Education Review, 2(3), 5-23.

Wang, D. (2011). The dilemma of time: student-centered teaching in the rural classroom in China. Teaching and Teacher Education, 27(1), 157-164. http://dx.doi.org/10.1016/j.tate.2010.07.012

Wang, M. C., Haertel, G. D., \& Walberg, H. J. (1993). Toward a knowledge base for school learning. Review of Educational Research, 6(3), 249-294. http://dx.doi.org/10.3102/00346543063003249

Watkins, D. A., \& Biggs, J. B. (2001). The paradox of the Chinese learner and beyond. In D. A. Watkins \& J. B. Biggs (Eds.). The Chinese learner: Cultural, psychological, and contextual influences (pp. 3-26). Hongkong: Comparative Education Research Center, The University of Hong Kong; Melbourne, Australia: Australian Council for Education Research.

Wayne, A. J., \& Youngs, P. (2003). Teacher characteristics and student achievement gains: A review. Review of Educational Research, 73(1), 89-122. http://dx.doi.org/10.3102/00346543073001089

Webb, N. M., Nemer, K. M., \& Ing, M. (2006). Small-group reflections: Parallels between teacher discourse and student behavior in peer-directed groups. The Journal of the Learning Sciences, 15(1), 63-119. http://dx.doi.org/10.1207/s15327809j1s1501_8

Wells, G. (1999). Dialogic inquiry: Towards a sociocultural practice and theory of education. Cambridge University Press. http://dx.doi.org/10.1017/CBO9780511605895

Wu, Y.J., Wu, K. N., Cheng, X. Q., \& Liu, Y. S. (1995). Structure of the time on the interaction in elementary school: from the sociological perspective [Woguo xiaoxue jiaowang shijian goucheng de shehuixue fenxi. Shanghai Jiaoyu Keyan]. Shanghai Research on Education, 5, 25-36.

Yackel, E., Cobb, P., \& Wood, T. (1991) Small-group interactions as a source of learning opportunities in second-grade mathematics. Journal for Research in Mathematics Education, 22(5), 390-408. http://dx.doi.org/10.2307/749187

Zhong, Q. (2006). Curriculum reform in China: Challenges and reflections. Frontiers of Education in China. 3(1), 370-382. http://dx.doi.org/10.1007/s11516-006-0014-3

Zimmermann, W., \& Cunningham, S. (Eds.). (1991). Visualization in teaching and learning mathematics. Washington, D.C.: American Mathematical Association.

Zhao, N., Valcke, M., Desoete, A., Verhaeghe, J., \& Xu, K. (2011). A multilevel analysis on predicting mathematics performance in Chinese primary schools: Implications for practice. The Asia-Pacific Education Research, 20(3), 503-520. 